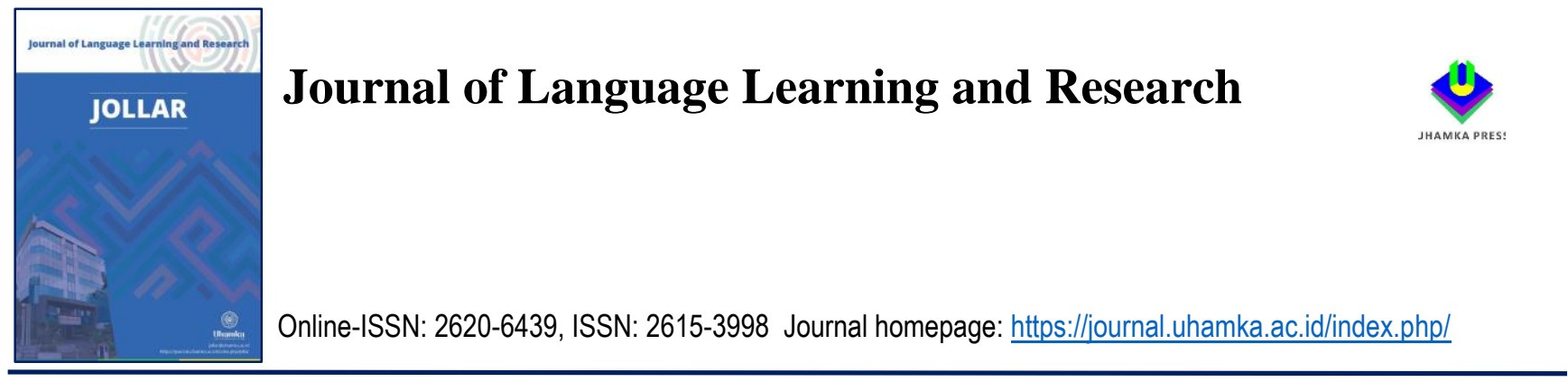

\title{
Tindak Tutur Komisif Politikus Pemenang Partai Pemilu di Indonesia Tahun 2019: Kajian Pragmatik
}

\author{
Yelmida | Wini Tarmini
}

How to cite : Yelmida \& Tarmini, W, 2020. Tindak Tutur Komisif Politikus Pemenang Partai Pemilu di Indonesia Tahun 2019: Kajian Pragmatik. Journal of Language Learning and Research. 1(1). 1-11. https://doi.org/10.22236/jollar.v3i1.7227

To link to this article: https://doi.org/10.22236/jollar.v3i1.7227

Opened Access Article๘

曲 Published Online on 11 Maret 2020

我 Submit your paper to this journal"

View Crossmark data $₫$ 


\title{
Tindak Tutur Komisif Politikus Pemenang Partai Pemilu di Indonesia Tahun 2019: Kajian Pragmatik
}

\author{
Yelmida ${ }^{1}$, Wini Tarmini $\bigotimes^{1}$
}

Received: 20 Desember 2020 Accepted: 6 Februari 2020 Published: 11 Maret 2020

\begin{abstract}
Abstrak
Penelitian ini bertujuan untuk mengetahui adanya tuturan komisif pada pidato politikus partai pemilu di Indonesia tahun 2019. Metode penelitian yang digunakan adalah metode kualitatif dengan pendekatan etnografi, fenomenologi, grounded theory, dan studi kasus. Hasil penelitian ini menunjukan: 1. Jenis tindak tutur komisif yang terdapat pada pidato politikus pemenang partai pemilu di Indonesia tahun 2019 ditemukan jenis tindak tutur berniat, berjanji, dan, menawarkan. 2 . Fungsi tindak tutur komisif politikus pemenang partai pemilu di Indonesia tahun 2019 terdiri atas 43 fungsi tindak tutur berniat ditandai dengan penanda gramatikal akan . 38 fungsi tindak tutur berjanji ditandai dengan penanda gramatikal harus, akan pasti dan InsyaAllah. 3 fungsi tindak tutur menawarkan ditandai dengan penanda gramatikal dapat, menawarkan. Tuturan bersumpah tidak ditemukan. Dengan demikian, kecenderungan yang paling banyak digunakan adalah tindak tutur janji yang komisif.
\end{abstract}

Kata kunci: tindak tutur, tuturan komisif, politikus.

\begin{abstract}
This research aims to find out the existence of commissive speeches in the speeches of election political parties in Indonesia in 2019. The research method used is a qualitative method with ethnographic, phenomenological, grounded theory, and case study approaches. The results of this study indicate: 1. Types of commissive speech acts found in the speeches of politicians who won electoral parties in Indonesia in 2019 found types of speech acts intended, promised, and offered. 2. The commissive speech acts of politicians who won the election party in Indonesia in 2019 consisted of 43 speech acts intended to be marked with grammatical markers. 38 speech act functions promise to be marked with definite grammatical must, will be sure and insyaAllah. 3 speech act functions offer marked with grammatical markers can, offer. Swear speech was not found. Thus, the most used tendency is commissive speech acts of promise.
\end{abstract}

Keywords: speech act, commissive speech, politician

Yelmida

yelmida06@gmail.com

Wini Tarmini

wini.tarmini@uhamka.ac.id

${ }^{1}$ Universitas Muhammadiyah Prof. DR. HAMKA 


\section{PENDAHULUAN}

Pragmatik merupakan studi bahasa yang membahas pemakaian bahasa dilihat dari konteks pemakaiannya. Pragmatik memiliki batasan yang berupa aturan pemakaian bahasa mengenai bentuk dan makna yang berkaitan dengan maksud penutur, konteks, serta keadaan. Parera (2001: 126) mengemukakan bahwa pragmatik merupakan kajian pemakaian bahasa dalam berkomunikasi yang berkaitan antara kalimat, konteks, situasi dan waktu ujaran dalam kalimat.

Pragmatik mempelajari mengenai maksud dari ujaran yaitu untuk apa ujaran dilakukan, menanyakan apa yang seseorang maksudkan dengan tindak tutur serta mengaitkan makna dengan siapa berbicara kepada siapa, di mana, bilamana dan bagaimana. Searle (dalam Rohmadi, 2004: 29) mengemukakan tindak tutur adalah hasil dari kalimat dalam kondisi tertentu yang berwujud pertanyaan, perintah dan yang lainnya. Tindak tutur merupakan tuturan yang terdapat dalam tindakan. Dengan mengucapkan sesuatu, penutur juga melakukan sesuatu. Dengan menuturkan sebuah ujaran, penutur memiliki tujuan yang ingin dicapai dari mitra tuturnya.

Bentuk komunikasi itu secara pragmatik terdapat tindak tutur komisif yang perlu dipahami secara komprehensif. Terpahaminya tindak tutur komisif secara pragmatis diharapkan dapat memperlancar komunikasi, meningkatkan kesantunan berkomunikasi, mengurangi kesalahpahaman berkomunikasi, dan memperjelas ketepatan pesan dalam komunikasi. Wijana (dalam Andarsari, 2015: 4) mengemukakan bahwa tindak tutur komisif mempunyai fungsi tertentu yang dapat diberi nama sesuai dengan maksud dan tujuan komunikasi. Tindak tutur komisif berupa menawarkan suatu hal, mengutarakan janji, dan mengutarakan nazar. Mengapa peneliti tertarik melakukan penelitian ini karena peristiwa tindak tutur politikus partai mempunyai peranan yang sangat penting dalam menyampaikan maksud dan tujuannya. Dalam pidato politikus partai pemilu di Indonesia banyak sekali variasi tindak tutur yang digunakan di antaranya adalah tindak tutur komisif. Pidato politikus partai pemilu menggunakan tindak tutur komisif untuk maksud dan tujuan politiknya. Tindak tutur komisif adalah tindak tutur yang mengikat penuturnya untuk melaksanakan apa yang disebutkan dalam tuturannya, seperti berjanji, bersumpah, berniat dan menawarkan. Selain itu tahun 2019 merupakan tahun yang sedang hangat diperbincangkan karena sedang berlangsungnya persaingan para politikus agar bisa mengambil hati masyarakat Indonesia untuk menduduki jabatan di gelanggang senayan.

Penelitian Tindak Tutur Komisif telah dilakukan oleh peneliti sebelumnya pada tahun 2015 yaitu Liska Andarsari dengan judul "Tindak Tutur Komisif Dalam Debat Pilkada Kabupaten Sambas Tahun 2015” yang hasilnya terdapat 19 tuturan komisif menawarkan atau mengusulkan yang pertuturannya menyatakan suatu tindakan bertutur yang disampaikan oleh penutur menjadi bahan pertimbangan bagi 
pendengar. Terdapat 47 tuturan komisif berjanji yang pertuturannya menyatakan suatu tindakan bertutur yang dilakukan oleh penutur dengan menyatakan janji akan melakukan suatu pekerjaan yang diminta orang lain serta 1 tuturan komisif bernazar yang kemunculannya dilatarbelakangi keinginan khusus, tetapi belum terlaksana. Adapun tujuan dari penelitian ini adalah untuk mengetahui variasi penggunaan tindak tutur komisif tahun 2019 yang tentu kondisinya berbeda dengan tahun 2015 . Dengan demikian, judul penelitian ini adalah "Tindak Tutur Komisif Politikus Partai Pemilu di Indonesia" yaitu diambil dua sample dari 14 partai yang ada di Indonesia yang dilihat dari suara terbanyak maka dari itu disebut sebagai politikus pemenang.

\section{METODE PENELITIAN}

Metode penelitian ini adalah penelitian deskriptif kualitatif sedangkan pendekatan yang digunakan adalah pendekatan kualitatif etnografi dan studi kasus. Penelitian ini menggambarkan fenomena sosial pemilu pada tahun 2019 yang terkait dengan tindak tutur politikus partai serta latar belakang politikus mempengaruhi penggunaan bahasa dan tuturannya. Selain itu data yang diambil dari video youtube, teks berita dan yang lainnya. Fokus penelitian pada tuturan komisif dan subfokusnya pada komisif berniat, berjanji, bersumpah dan menawarkan dalam pidato politikus partai. Sumber data dalam penelitian ini diambil dari dokumen, buku-buku dan peristiwa pemilu yang direkam melalui video youtube yang ada di Indonesia sedangkan datanya adalah tuturan-tuturan komisif politikus partai pemilu. Peneliti menjelaskan informasi atau data yang dikumpulkan sehubungan dengan fokus dan subfokus penelitian, serta sumber data primer maupun sekunder yang digunakan dalam penelitian baik sebagai informan, peristiwa, maupun dokumen.

\section{TEMUAN DAN PEMBAHASAN}

Berdasarkan hasil analisis data, dapat dikemukakan hasil penelitian sebagai berikut:

1. Jenis tindak tutur komisif yang terdapat pada pidato politikus pemenang partai pemilu di Indonesia tahun 2019 ditemukan jenis tindak tutur berniat, berjanji, dan, menawarkan.

2. Fungsi tindak tutur komisif politikus pemenang partai pemilu di Indonesia tahun 2019 terdiri atas 43 fungsi tindak tutur berniat dengan presentase 51\% digunakan untuk memaknai bahwa sesuatu akan dilakukan apabila permintaannya disetujui lawan tutur. 38 fungsi tindak tutur berjanji dengan presentase $45 \%$ digunakan untuk memaknai bahwa sesuatu pasti dilakukan apabila permintaannya disetujui lawan tuturnya. 3 fungsi tindak tutur menawarkan dengan presentase $4 \%$ digunakan untuk memaknai bahwa menawarkan sesuatu apabila permintaannya disetujui lawan tuturnya. 
Tindak tutur bersumpah tidak ditemukan. Dengan demikian, kecenderungan yang paling banyak digunakan adalah tindak tutur komisif berniat. Hasil penelitian tindak tutur komisif politikus partai pemilu tahun 2019 dapat digambarkan pada bagan berikut ini.

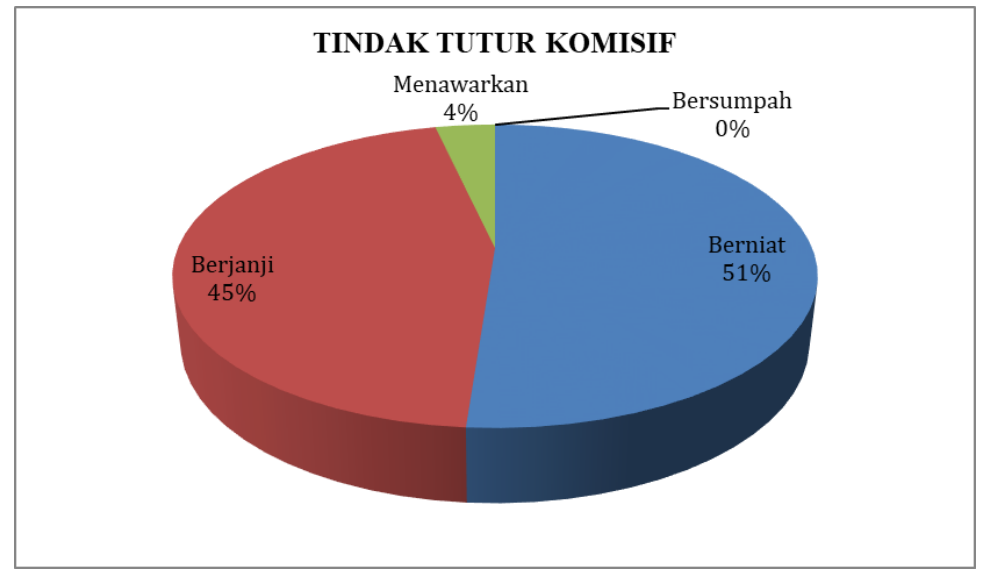

\section{Bagan 1.1 Hasil Presentasi Penelitian}

Berdasarkan hasil klasifikasi dan analisis data, dapat dikemukakan tindak tutur komisif berniat, berjanji, dan menawakan dalam paparan berikut ini

\section{(1)Komisif Berniat}

Berdasarkan hasil klasifikasi data dan analisis data ditemukan data komisif berniat sebanyak 43 data tuturan, yaitu data [1], [2], [3], [5], [8], [11], [13], [19], [22], [23], [24], [26], [28], [30], [33], [35], [36], [37], [42], [43], [44], [48], [49], [50], [51], [52], [53], [54], [55], [57], [62], [64], [66], [68], [69], [70], [76], [79], [80], [81], [82], [83], [84].

Berikut ini adalah contoh tabel analisis tindak tutur komisif berniat

\begin{tabular}{|c|c|c|c|}
\hline No & $\begin{array}{c}\text { No } \\
\text { Data }\end{array}$ & Data Tuturan & Keterangan \\
\hline 1 & 1 & $\begin{array}{l}\text { Kita perlu memilih } \\
\text { pemerintah yang akan } \\
\text { menghentikan perampokan } \\
\text { ini. }\end{array}$ & $\begin{array}{l}\text { Dikatakan komisif berniat } \\
\text { karena terdapat penanda } \\
\text { gramatikal akan yang memiliki } \\
\text { makna hendak menurut KBBI V } \\
\text { menghentikan perampokan. }\end{array}$ \\
\hline 2 & 2 & $\begin{array}{lr}\text { Atas dasar keyakinan ini } \\
\text { kami ingin } & \text { seluruh } \\
\text { masyarakat } & \text { Indonesia } \\
\text { mengerti betul } & \end{array}$ & $\begin{array}{l}\text { Dikatakan komisif berniat } \\
\text { karena terdapat penanda } \\
\text { gramatikal kami ingin yang } \\
\text { memiliki makna hendak menurut } \\
\text { KBBI V mengerti apa yang } \\
\text { diperjuangkan. }\end{array}$ \\
\hline
\end{tabular}




\begin{tabular}{|c|c|c|c|}
\hline 3 & 3 & $\begin{array}{l}\text { Apa yang akan kami } \\
\text { perjuangkan selama lima } \\
\text { tahun mendatang jika kami } \\
\text { dan partai- partai politik } \\
\text { yang tergabung dalam } \\
\text { koalisi Indonesia adil } \\
\text { makmur mendapat mandat } \\
\text { dari rakyat pada pemilihan } \\
\text { umum 17 April } 2019 \text { yang } \\
\text { akan datang }\end{array}$ & $\begin{array}{l}\text { Dikatakan komisif berniat } \\
\text { karena terdapat penanda } \\
\text { gramatikal akan yang memiliki } \\
\text { makna sesuatu yang hendak } \\
\text { menurut KBBI V mengerti apa } \\
\text { yang diperjuangkan selama lima } \\
\text { tahun ke depan. }\end{array}$ \\
\hline 4 & 5 & $\begin{array}{l}\text { Kami juga } \text { ingin } \\
\text { menyampaikan kepada } \\
\text { saudara apa- apa yang } \\
\text { menjadi kegusaran kami. }\end{array}$ & $\begin{array}{l}\text { Dikatakan komisif berniat } \\
\text { karena terdapat penanda } \\
\text { gramatikal ingin yang memiliki } \\
\text { makna hendak menurut KBBI V } \\
\text { menyampaikan apa yang } \\
\text { menjadi kegusaran atau } \\
\text { kekhawatiran kami. }\end{array}$ \\
\hline
\end{tabular}

Beberapa contoh data komisif berniat dijelaskan dalam paparan berikut ini

a. [1] Kita perlu memilih pemerintah yang akan menghentikan perampokan ini.

b. [2] Atas dasar keyakinan ini kami ingin seluruh masyarakat Indonesia mengerti betul.

c. [3] Apa yang akan kami perjuangkan selama lima tahun mendatang jika kami dan partai- partai politik yang tergabung dalam koalisi Indonesia adil makmur mendapat mandat dari rakyat pada pemilihan umum 17 April 2019 yang akan datang.

d. [5] Kami juga ingin menyampaikan kepada saudara apa- apa yang menjadi kegusaran kami.

Pada contoh kalimat 1 [data 2] dapat dikemukakan bahwa tuturan politikus komisif berniat menggunakan penanda gramatikal kata ingin yang bermakna hendak atau mau melakukan sesuatu apabila permintaannya disetujui lawan tutur.

Pada contoh kalimat 2 [data 2], kalimat 3 [data 3], kalimat 4 [data 5], dapat dikemukakan bahwa tuturan politikus komisif berniat memiliki makna bahwa hendak atau mau melakukan sesuatu apabila permintaannya disetujui lawan tutur.

\section{(2)Komisif Berjanji}

Berdasarkan hasil klasifikasi data dan analisis data ditemukan data komisif berjanji sebanyak 38 data tuturan, yaitu data [9], [10], [12], [14], [15], [16], [17], [18], [20], [21], [25], [27], [29], [31], [32], [34], [38], [39], [40], [41], [45], [46], [47], [56], [58], [59], [60], [61], [63], [65], [67], [71], [72], [73], [74] [75], [77], [78].

Berikut ini adalah contoh tabel analisis tindak tutur komisif berjanji 


\begin{tabular}{|c|c|c|c|}
\hline No & $\begin{array}{c}\text { No } \\
\text { Data }\end{array}$ & Berjanji & Keterangan \\
\hline 1 & 9 & $\begin{array}{l}\text { Yang ketiga kita harus } \\
\text { swasembada air bersih. } \\
\text { PBB meramalkan bahwa } \\
\text { dalam dua ribu dua lima } \\
\text { seluruh bumi akan } \\
\text { mengalami krisis air }\end{array}$ & $\begin{array}{l}\text { Dikatakan komisif berjanji karena } \\
\text { terdapat penanda gramatikal harus } \\
\text { menurut KBBI V memiliki makna patut } \\
\text { dan wajib swsembada air bersih kalau } \\
\text { terpilih sebagai pemimpin atau politikus. }\end{array}$ \\
\hline 2 & 10 & $\begin{array}{l}\begin{array}{l}\text { Yang keempat Negara } \\
\text { yang kokoh harus } \\
\text { memiliki lembaga- } \\
\text { lembaga pemerintahan }\end{array} \\
\text { yang kuat, yang bersih, } \\
\text { yang berintegritas. Kita } \\
\text { perlu hakim- hakim yang } \\
\text { unggul dan jujur. } \\
\text { Keadilan dibidang } \\
\text { hukum dan demokrasi } \\
\text { berkualitas. }\end{array}$ & $\begin{array}{l}\text { Dikatakan komisif berjanji karena } \\
\text { terdapat penanda gramatikal harus } \\
\text { menurut KBBI V memiliki makna patut } \\
\text { atau wajib memiliki lembaga } \\
\text { pemerintahan yang kuat kalau terpilih } \\
\text { sebagai pemimpin atau politikus. }\end{array}$ \\
\hline 3 & 12 & $\begin{array}{l}\text { Strategi ini harus dapat } \\
\text { mewujudkan tadi yang } \\
\text { kita sebut swasembada- } \\
\text { swasembada, } \\
\text { swasembada pangan, } \\
\text { swasembada energi, } \\
\text { swasembada air bersih, } \\
\text { membangun lembaga- } \\
\text { lembaga pemerintah } \\
\text { yang kuat dan memiliki } \\
\text { pertahanan yang kokoh } \\
\text { yang bisa melindungi } \\
\text { segenap bangsa tumpah } \\
\text { darah Indonesia. }\end{array}$ & $\begin{array}{l}\text { Dikatakan komisif berjanji karena } \\
\text { terdapat penanda gramatikal harus } \\
\text { menurut KBBI V memiliki makna patut } \\
\text { atau wajib mewujudkan swasembada } \\
\text { pangan, energi dan air. }\end{array}$ \\
\hline 4 & 14 & $\begin{array}{l}\text { Dan kita yakin dapat } \\
\text { meningkatkan daya beli } \\
\text { rakyat, daya beli } \\
\text { masyarakat. }\end{array}$ & $\begin{array}{l}\text { Dikatakan } \text { komisif } \text { berjanji } \\
\text { terdapat penanda gramatikal yakin } \\
\text { menurut KBBI V memiliki makna } \\
\text { percaya dan } \\
\text { meningkatkan daya beli rakyat kalau } \\
\text { terpilih sebagai pemimpin atau politikus. }\end{array}$ \\
\hline 5 & 15 & $\begin{array}{l}\text { Kita harus hentikan } \\
\text { mengalirnya uang baru } \\
\text { Indonesia ke luar negeri. }\end{array}$ & $\begin{array}{l}\text { Dikatakan komisif berjanji karena } \\
\text { terdapat penanda gramatikal harus } \\
\text { menurut KBBI V memiliki makna patut } \\
\text { atau wajib menghentikan mengalirnya } \\
\text { uang baru Indonesia ke luar negeri kalau } \\
\text { terpilih sebagai pemimpin atau politikus. }\end{array}$ \\
\hline
\end{tabular}


Beberapa contoh data komisif berjanji dijelaskan dalam paparan berikut ini.

a. [9] Yang ketiga kita harus swasembada air bersih. PBB meramalkan bahwa dalam dua ribu dua lima seluruh bumi akan mengalami krisis air.

b. [10] Yang keempat Negara yang kokoh harus memiliki lembaga-lembaga pemerintahan yang kuat, yang bersih, yang berintegritas. Kita perlu hakimhakim yang unggul dan jujur. Keadilan dibidang hukum dan demokrasi berkualitas.

c. [12] Strategi ini harus dapat mewujudkan tadi yang kita sebut swasembadaswasembada, swasembada pangan, swasembada energi, swasembada air bersih, membangun lembaga-lembaga pemerintah yang kuat dan memiliki pertahanan yang kokoh yang bisa melindungi segenap bangsa tumpah darah Indonesia.

d. [14] Dan kita yakin dapat meningkatkan daya beli rakyat, daya beli masyarakat. e. [15] Kita harus hentikan mengalirnya uang baru Indonesia ke luar negeri Pada contoh kalimat 1 [data 9]. Kalimat 2 [data 10], kalimat 3 [data 12], kalimat 4 [14], dan kalimat 5 [data 15] dapat dikemukakan bahwa tuturan komisif berjanji memiliki makna bahwa sesuatu harus, patut, wajib dan pasti dilakukan apabila permintaannya disetujui lawan tutur.

Dalam tuturan komisif berjanji menggunakan penanda gramatikal kata harus, pasti, dan akan pastikan tergantung dari teksnya.

\section{(3)Komisif Menawarkan}

Berdasarkan hasil klasifikasi data dan analisis data ditemukan data komisif menawarkan sebanyak 3 data tuturan, yaitu pada data [4], [6], dan [7]

Berikut ini adalah contoh tabel analisis tindak tutur komisif menawarkan

\begin{tabular}{|c|c|c|c|}
\hline No & $\begin{array}{c}\text { No } \\
\text { Data }\end{array}$ & Menawarkan & Keterangan \\
\hline 1 & 4 & $\begin{array}{ll}\text { Kami maju, } & \text { kami } \\
\text { menawarkan diri, } & \text { kami } \\
\text { yakin hal ini tidak boleh } \\
\text { terjadi dalam Negara yang } \\
\text { sudah merdeka. }\end{array}$ & $\begin{array}{l}\text { Dikatakan komisif menawarkan } \\
\text { karena terdapat penanda } \\
\text { gramatikal menawarkan diri } \\
\text { menurut KBBI V memiliki } \\
\text { makna bersedia melakukan } \\
\text { sesuatu untuk orang lain apabila } \\
\text { terpilih menjadi pemimpin atau } \\
\text { politikus. }\end{array}$ \\
\hline 2 & 6 & $\begin{array}{l}\text { Apa-apa yang mendorong } \\
\text { kami untuk terus berjuang dan } \\
\text { terus berada di dalam kancah } \\
\text { politik dan menawarkan diri } \\
\text { kami untuk memimpin dan } \\
\text { membela Negara kesatuan } \\
\text { republik Indonesia. }\end{array}$ & $\begin{array}{l}\text { Dikatakan komisif menawarkan } \\
\text { karena terdapat penanda } \\
\text { gramatikal menawarkan diri } \\
\text { menurut KBBI V memiliki } \\
\text { makna bersedia melakukan } \\
\text { sesuatu apabila terpilih menjadi } \\
\text { pemimpin atau politikus. }\end{array}$ \\
\hline
\end{tabular}




\begin{tabular}{llll}
\hline 3 & Kami saya bersama Sandiaga & Dikatakan komisif menawarkan \\
Uno kami maju menawarkan & karena terdapat penanda \\
& diri mengabdi, berbakti & gramatikal menawarkan diri \\
karena kami percaya dan & menurut KBBI V memiliki \\
yakin hal ini tidak boleh & makna bersedia melakukan \\
terjadi dalam negara yang & sesuatu untuk orang lain dengan \\
& sudah merdeka. & mengabdikan diri untuk Negara \\
& dan rakyat Indonesia.
\end{tabular}

Beberapa contoh data komisif menawarkan dijelaskan dlam paparan berikut.

a. [4] Kami maju, kami menawarkan diri, kami yakin hal ini tidak boleh terjadi dalam Negara yang sudah merdeka.

b. [6] Apa-apa yang mendorong kami untuk terus berjuang dan terus berada di dalam kancah politik dan menawarkan diri kami untuk memimpin dan membela Negara kesatuan republik Indonesia.

c. [7] Kami saya bersama Sandiaga Uno kami maju menawarkan diri mengabdi, berbakti karena kami percaya dan yakin hal ini tidak boleh terjadi dalam negara yang sudah merdeka.

Pada contoh kalimat 1 [data 4]. Kalimat 2 [data 6], dan kalimat 3 [data 7], dapat dikemukakan bahwa tuturan komisif menawarkan diri memiliki makna untuk bersedia melakukan sesuatu untuk orang lain. Dalam tuturan komisif menawarkan menggunakan penanda gramatikal kata menawarkan.

\section{KESIMPULAN}

Berdasarkan hasil analisis data penelitian yang telah dilakukan, simpulan yang dapat dikemukan bahwa jenis tindak tutur komisif yang terdapat pada pidato politikus pemenang partai pemilu di Indonesia tahun 2019 ditemukan jenis tindak tutur berniat, berjanji, dan, menawarkan. Fungsi tindak tutur komisif politikus pemenang partai pemilu di Indonesia tahun 2019 terdiri atas 43 fungsi tindak tutur berniat ditandai dengan penanda gramatikal akan, ingin, tekad atau bertekad. 38 fungsi tindak tutur berjanji ditandai dengan penanda gramatikal akan pasti, insyaAllah dan harus. 3 fungsi tindak tutur menawarkan ditandai dengan penanda gramatikal menawarkan dan menawarkan diri. Tindak tutur bersumpah tidak ditemukan. Dengan demikian, kecenderungan yang paling banyak digunakan adalah tindak tutur komisif berniat.

Dari penelitian ini bagaimana pidato politikus dapatkan dikaitkan dalam kegiatan Proses Belajar Mengajar (PBM) pada mata pelajaran Bahasa Indonesia lebihnya tepatnya pada keterampilan berbicara. Hal ini dapat diterapkan pada guru 
dan siswa. Dalam pembelajaran Bahasa Indonesia seorang guru harus variatif dan kreatif dalam menyampaikan materi pelajaran seperti menggunakan media gambar, video, audio dan praktek. Hal ini bertujuan agar siswa tidak merasa bosan selama jam pelajaran berlangsung. Dengan guru menerapkan pembelajaran secara variatif akan menumbuhkan semangat siswa dalam belajar, walaupun mata pelajaran Bahasa Indonesia lebih banyak membahas mengenai teks, tetapi kalau guru mampu memanfaatkan media pembelajaran yang bermacam-macam maka siswa tidak akan merasa bosan dan jenuh lagi. Bagi siswa hal ini bertujuan untuk melihat penggunaan kesantunan berbahasa yang digunakan oleh politikus ketika berkampanye sudah sesuai atau belum. Jika seorang politikus menggunakan kesantunan dalam berbahasa maka hal itu wajib dijadikan contoh atau terapan pada siswa.

Berdasarkan simpulan hasil analisis data penelitian yang telah dikemukakan di atas, saran yang dapat diberikan diantaranya para pendengar atau mitra tutur hendaknya memperhatikan maksud dan tujuan yang ingin disampaikan oleh penutur dalam sebuah komunikasi berbahasa, sehingga dapat terjalin komunikasi yang lancar dan tepat sasaran antara penutur dan mitra tutur. Para peneliti bahasa selanjutnya mampu memanfaatkan hasil penelitian ini sebagai referensi penelitian, khususnya penelitian mengenai tindak tutur. Para peneliti bahasa lainnya diharapkan dapat mengembangkan penelitian yang lebih bervariasi dan mendalam dalam bidang kajian pragmatik maupun bidang kajian bahasa lainnya.

\section{DAFTAR PUSTAKA}

Andrasari, L. (2017). Tindak Tutur Komisif Dalam Debat Pilkada Kabupaten Sambas Tahun 2015. Jurnal Pendidikan dan Pembelajaran Peristiwa, 6(4), 6-8. Diunduh tanggal 2 Februari 2020, dari https://jurnal.untan.ac.id/index.php/jpdpb/article/view/19835/16285.

Apriastuti, N. (2017). Bentuk, Fungsi dan Jenis Tindak Tutur Dalam Komunikasi Siswa di Kelas IX Unggulan SMP PGRI Denpasar Tahun 2017. Jurnal Ilmiah Pendidikan dan Pembelajaran Pps Universitas Pendidikan Ganesha, 1(1), 44. Diunduh tanggal 26 Februari 2020 pukul 22.00, dari https://ejournal.undiksha.ac.id/index.php/JIPP/article/viewFile/11960/76 $\underline{31}$

Azimah, S. (2016) Tindak Tutur Komisif Dalam Film Soekarno Karya Hanung Bramantyo. Skripsi. Fakultas Bahasa dan Seni, Universitas Negeri Semarang. Diunduh tanggal 20 Januari 2020 pukul 14.00, dari https://lib.unnes.ac.id/28724/1/2111412029.pdf.

Devianty, R. (2017). Bahasa Sebagai Cermin Kebudayaan. Jurnal Tarbiyah, Vol.24, No. 2, Juli-Desember 2017. ISSN: 0854-2627. Diunduh tanggal 5 Maret 2020 pukul 15.00 , dari http://jurnaltarbiyah.uinsu.ac.id/index.php/tarbiyah/article/view/167/211. 
Hariantati, R. (2003). Etika Politik dalam Negara Demokrasi. Demokrasi Vol. II No. 1 Th. 2003. Diunduh tanggal 14 Maret 2020 pukul 23.00, dari https://ilmupolitikfisipuho.com/wp-content/uploads/2019/05/etikapolitik.pdf.

Hasanudin Dede, Jupri Rahman Abdul. 2014. Teori Belajar Bahasa Indonesia.Jakarta: Mitra Wacana Media.

Istikoma, N. (2019). Bentuk Tindak Ekspresif dan Komisif Dalam Debat Cawapres Pilpres 2019 Putaran Ke-3. Seminar Nasional SAGA\# (Sastra, Pedagogik, dan Bahasa). 2(2), 27. Diunduh tanggal 26 Januari 2020 pukul 20.00, dari http://seminar.uad.ac.id/index.php/saga/article/view/2740/693.

Khasanah, N. (2017). Tindak Tutur Komisif Pedagang Perempuan di Pasar Induk Bandar Jaya dan Implikasinya Tahun 2017. Jurnal Kata (Bahasa, Sastra dan Pembelajarannya), 5(4), 2-3. Diunduh tanggal 25 Januari 2020 pukul 13.00, dari http://jurnal.fkip.unila.ac.id/index.php/BINDO1/article/view/14136/1022 1.

Manurtawan, Hermawan, Sadyana. (2019). Tindak Tutur Komisif Dalam Dorama'Kazoku Game Tahun 2019. Jurnal Pendidikan Bahasa Jepang Undiskha, 5(3), 317-319. Diunduh tanggal 22 Februari 2020 pukul 21.00, dari

https://ejournal.undiksha.ac.id/index.php/JJPBJ/article/view/21426/1379 $\underline{5}$.

Nambo, Puluhuluwa. (2005). Memahami Tentang Beberapa Konsep Politik (Suatu Telaah dari Sistem Politik). Volume XXI No. 2 April - Juni 2005: 262285. Diunduh tanggal 21 Januari 2020 pukul 15.00, dari https://media.neliti.com/media/publications/154709-ID-memahamitentang-beberapa-konsep-politik.pdf.

Sari, F. (2012). Tindak Tutur dan Fungsi Tuturan Ekspresif Dalam Acara Galau Nite di Metro TV: Suatu Kajian Pragmatik. Jurnal Unair, Skiptorium, Vol. 1, No. 2. Diunduh tanggal 25 Maret 2020 pukul 14.00, dari http://www.journal.unair.ac.id/download-fullpapersskriptorium882d24b95efull.pdf.

Silampari (2018). Tindak Tutur Ekspresif dalam film kehormatan di balikkerudung Sutradara Tyo.Vol 1, No (1). Diunduh tanggal 14 Januari 2020 pukul 19.00, dari https://media.neliti.com/media/publications/255411-tindaktutur-ekspresif-dalam-film-kehorm-c80d8d98.pdf.

Triwahyuni, S. (2019). Tindak Tutur Komisif Penjual dan Pembeli di Pasar Tradisional Gunung Batu Tanggamus Tahun 2019. Jurnal Kata (Bahasa, Sastra dan Pembelajarannya) Januari 2019, 7(1), 2-3. Diunduh tanggal 1 Januari 2020 pukul 21.00, dari http://jurnal.fkip.unila.ac.id/index.php/BINDO1/article/view/17435/1239 1 .

Wahyono, H. (2015).Variasi Tindak Tutur Dalam Cerpen “Tergoda” Karya Dewi Anggraeni. Jurnal Transformatika, Volume 11, Nomor 2, September ISSN 0854-8412. 
Yanto, Rusminto, Tarmini. (2013). Representasi Kekuasaan Pada Tindak Tutur Guru dalam Pembelajaran Bahasa Indonesia. J-Simbol (Bahasa, Sastra dan Pembelajarannya) Vol 1, No 2, (2013). Diunduh tanggal 6 Februari 2020 pukul 22.00,

dari http://jurnal.fkip.unila.ac.id/index.php/BINDO/article/view/4482. 